BIOMEDICAL AND BIOSOCIAL ANTHROPOLOGY
$\begin{gathered}\text { Official Journal of the International Academy } \\ \text { of Integrative Anthropology } \\ \text { journal homepage: http://bba-journal.com }\end{gathered}$

\title{
Features of the girth sizes of the body in men with various forms of eczema
}

\author{
Al-Omary Ala'a Osama Ahmad, Dmitrenko S. V., Drachuk O. P., Yasko V. V., Gunas I. V.
}

National Pirogov Memorial Medical University, Vinnytsya, Ukraine

\section{ARTICLE INFO}

Received: 11 September, 2020

Accepted: 13 October, 2020

UDC: $616.379-$

008.64:577.112:616.61-07-084

\section{CORRESPONDING AUTHOR}

e-mail: svetlana7783@ukr.net Dmitrenko S. V.

\begin{abstract}
Prediction of the occurrence of eczema and the development of its severe forms is possible by identifying its morphological markers in patients with various forms and severity of dermatosis and their comparison with healthy subjects. The aim of the study was to examine the differences in body girth sizes between healthy and/or eczema patients depending on the severity of dermatosis. Patients with idiopathic $(n=34)$ and microbial $(n=38)$ eczema men of the first mature age underwent an anthropometric examination according to Bunak. The diagnosis of eczema was made according to the nomenclature of ICD-10. As a control from the data bank of the research center of National Pirogov Memorial Medical University, Vinnytsya anthropometric data of 82 practically healthy men of the same age group were selected. Statistical data processing was performed in the license package "Statistica 5.5" using non-parametric methods of evaluation of the obtained results. In healthy men, the following values of the following envelope sizes were found: shoulder girth in a tense state by $4.9 \%$ compared with patients with severe eczema; unstressed shoulder girth by $7.3 \%$ and $11.8 \%$ compared with patients with idiopathic eczema of mild and severe course and by $10.0 \%$ and $11.3 \%$ compared with patients with microbial eczema of mild and severe course; forearm girth in the upper part by $5.4 \%$ compared with patients with idiopathic eczema of severe course; thigh girth by $5.1 \%$ and $8.0 \%$ compared with patients with idiopathic eczema of mild and severe course and by $7.1 \%$ and $11.3 \%$ compared with patients with microbial eczema of mild and severe course; thigh girth by $4.16 \%$ and $4.5 \%$ compared with patients with idiopathic severe eczema and mild microbial eczema; upper crus girth by $5.3 \%, 7.5 \%$ and $7.1 \%$ compared with patients with idiopathic eczema of mild and severe course and microbial eczema of mild course; lower crus girth by $6.0 \%$ compared with patients with mild microbial eczema; neck girth by $7.5 \%$ and $6.8 \%$ compared with patients with idiopathic severe eczema and mild microbial eczema; waist girth by $8.6 \%$ and $15.6 \%$ compared with patients with idiopathic eczema of mild and severe course and by $13.9 \%$ and $16.7 \%$ compared with patients with microbial eczema of mild and severe course; chest girth on inhalation, exhalation, at rest by 6.9 $\%, 9.5 \%$ and $9.1 \%$ compared with patients with idiopathic eczema of severe course. Only the girth of the foot in healthy men is $3.1 \%$ higher than in sick men with mild microbial eczema. In men with idiopathic eczema, the neck girth was $5.4 \%$ lower than in men with severe eczema. The obtained data can be used for a personalized approach in the creation of appropriate prevention and treatment and diagnostic programs. Keywords: eczema, girth sizes of body, men.
\end{abstract}

\section{Introduction}

The problem of eczema is becoming increasingly important. In the structure of the incidence of chronic dermatoses, it accounts for up to $40 \%$ of all skin diseases. The incidence of this dermatitis is observed in all age groups and is often verified as an occupational disease. According to epidemiological studies, different types of eczema are the most common of all dermatoses in the practice of dermatovenereology [1, 4].

Today, the focus of interest in scientific medical research is directed not only to the study of the causes of pathological processes, but also to the mechanisms of resistance to their occurrence and development. An important place in 
the assessment of resistance to risk factors is occupied by the study of molecular, cellular mechanisms of protection, and morphofunctional parameters of the organism. This is due to the fact that the anthropological approach in medicine ranges from the establishment of general laws to determine the adaptive significance of phenotypic polymorphism in the population $[10,11,14]$.

Modern integrative and personalized medicine requires the creation of standards of physical development of different groups of the population, which could be guided by the examination of a particular patient [6]. The creation of such standards as one of the most important tasks of modern anthropology should take into account the diversity of the population and be carried out taking into account constitutional, sex, age, ethno-territorial factors [15]. Implementation of this direction without the accumulation of a large array of morphometric data is impossible [17].

In dermatology, in particular, over the last decade, positive experience has been accumulated in the application of constitutional parameters, which is promising for both diagnosis and prognosis of pathology. Thus, the systematic application of constitutional characteristics in the creation of an individual approach to diagnosis on the example of atopic dermatitis, pyoderma, psoriasis, and others $[5,8,9,12]$ allowed to speak not only about the urgency of the problem of phenotypic manifestation of dermatoses, but also to apply in the systemic aspect of the constitutional approach in solving the problem of their prediction. It should be acknowledged that many issues related to the strategic task described above have not yet been fully resolved. In particular, in Ukraine for eczema there is practically no data on "somatotypological profiles" and on features of dimensional indicators depending on the form and weight of its course.

The aim of the study was to identify the differences in body girth sizes between healthy and/or eczema patients depending on the severity of dermatosis.

\section{Materials and methods}

Men of the first mature age (22-35 years) with idiopathic ( $n=34$, including 16 mild and 18 severe severity) and microbial ( $n=38$, including 28 mild and 10 severe severity) eczema, who were examined on the basis of the Military Medical Clinical Center of the Central Region and the Department of Skin and Venereal Diseases with a course of postgraduate education of National Pirogov Memorial Medical University, Vinnytsya, conducted an anthropometric survey in accordance with the scheme of Bunak V. V. [2].

The diagnosis of eczema was performed according to the nomenclature ICD-10 (https://zakononline.com.ua/ documents/show/116857_531218).

As a control from the data bank of the research center of Vinnytsia National Medical University anthropometric data of 82 practically healthy men of the same age group were selected.

Statistical data processing was performed in the license package "Statistica 5.5" using non-parametric methods of evaluation of the obtained results. The reliability of the difference between the values between the independent quantitative values was determined using the MannWhitney U-test.

\section{Results}

In healthy men, compared with patients, lower values were found:

shoulder girth in a tense state $(33.23 \pm 2.84)$ compared with men suffering from the idiopathic severe eczema (35.31 $\pm 3.65 ; p<0.05)$ (Fig. 1);

shoulder girth in the unstressed state $(30.17 \pm 2.94)$ compared with men with idiopathic eczema of the mild (32.56 $\pm 3.96 ; p=0.055)$ and severe severity $(34.19 \pm 3.82$; $p<0.05)$ and microbial eczema of the mild $(33.52 \pm 3.71$; $p<0.001)$ and severe severity $(33.95 \pm 4.92 ; p<0.05)$ (Fig. 2);

forearm girth in the upper part $(27.33 \pm 2.01)$ compared with men suffering from the idiopathic severe eczema

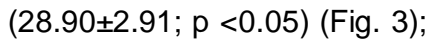

thigh girth $(53.25 \pm 4.49)$ compared with men with idiopathic eczema of the mild $(56.06 \pm 5.25 ; p=0.062)$ and severe $(57.87 \pm 4.68 ; p<0.001)$ severity and microbial eczema of the mild $(57.34 \pm 6.66 ; p<0.01)$ and severe severity (57.70 $\pm 7.56 ; p=0.053$ ) (Fig. 4);

thigh girth in healthy men $(95.04 \pm 6.39)$ compared with sick men with idiopathic eczema of mild course $(99.58 \pm 6.34$; $\mathrm{p}<0.05)$ and microbial eczema of mild course $(99.48 \pm 9.49$; $\mathrm{p}=0.054$ ) (Fig. 5);

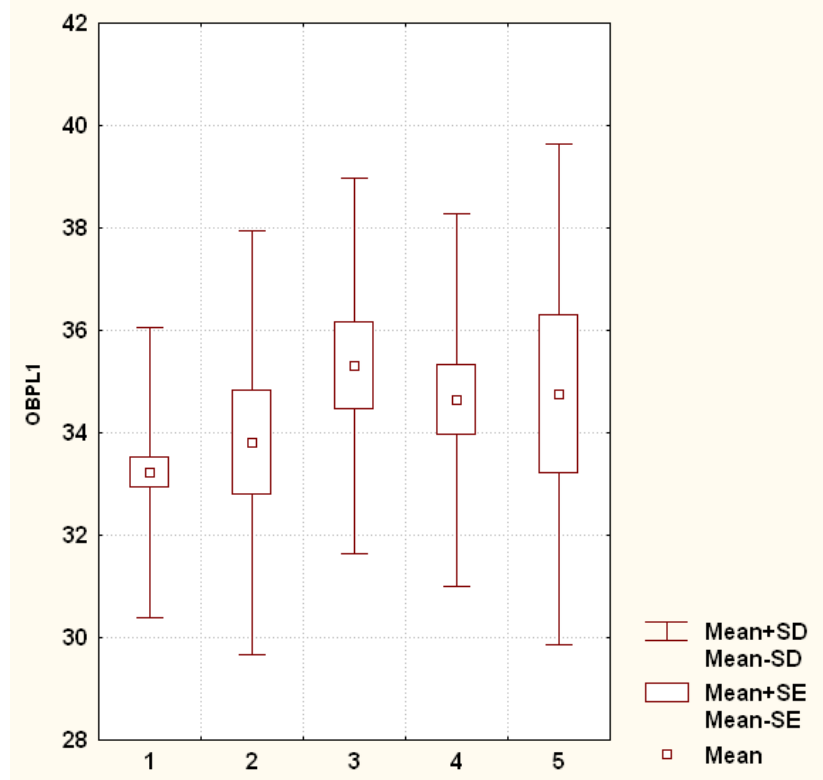

Fig. 1. Shoulder girth in a tense state (OBPL1) in healthy and sick men with various forms of eczema $(\mathrm{cm})$. In this and the following figures: 1 - healthy men; 2 - men suffering from the idiopathic mild eczema; 3 - men suffering from the idiopathic severe eczema; 4 men with microbial eczema of mild course; 5 - men with severe microbial eczema; Mean - average value; Mean \pm SE - average value \pm mean error; Mean $\pm S D$ - mean \pm standard deviation. 


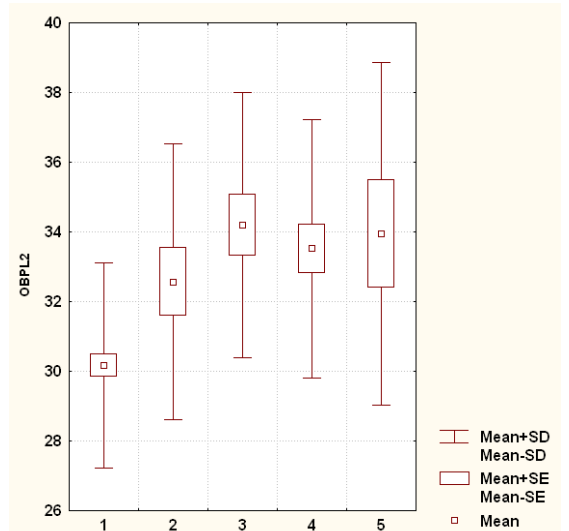

Fig. 2. Shoulder girth in the unstressed state (OBPL2) in healthy and sick men with various forms of eczema $(\mathrm{cm})$.
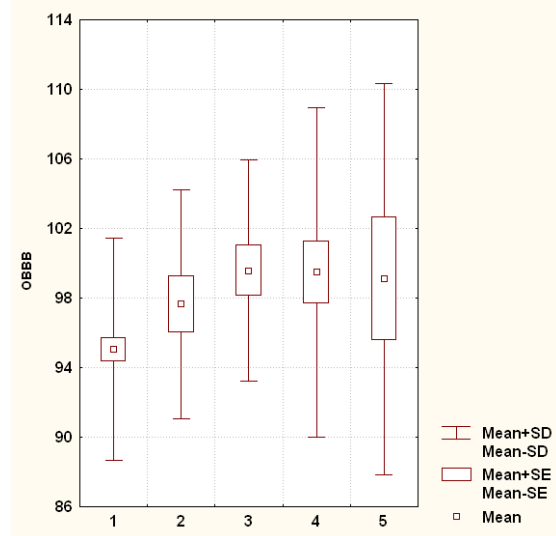

Fig. 5. Thigh girth (OBBB) in healthy and sick men with various forms of eczema $(\mathrm{cm})$.
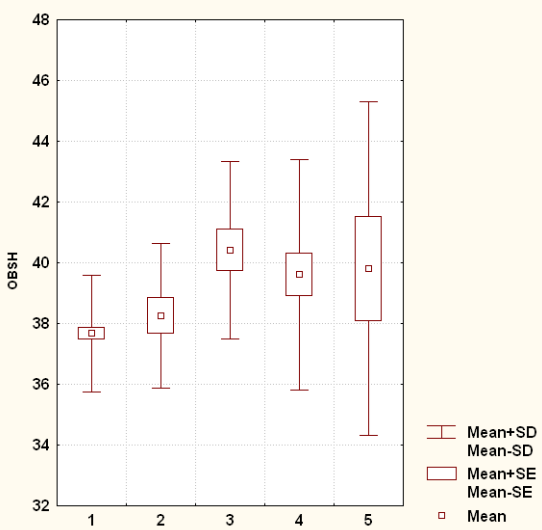

Fig. 8. Neck girth (OBSH) in healthy and sick men with various forms of eczema $(\mathrm{cm})$.

upper crus girth $(36.43 \pm 2.91)$ compared with men with idiopathic eczema of mild $(38.46 \pm 3.75 ; p=0.075)$ and severe eczema $(39.39 \pm 3.45 ; p<0.01)$ and microbial eczema of mild course $(39.21 \pm 3.51 ; p<0.001)$ (Fig. 6);

crus girth in the lower part $(23.41 \pm 1.87)$ compared with eczema $(\mathrm{cm})$.
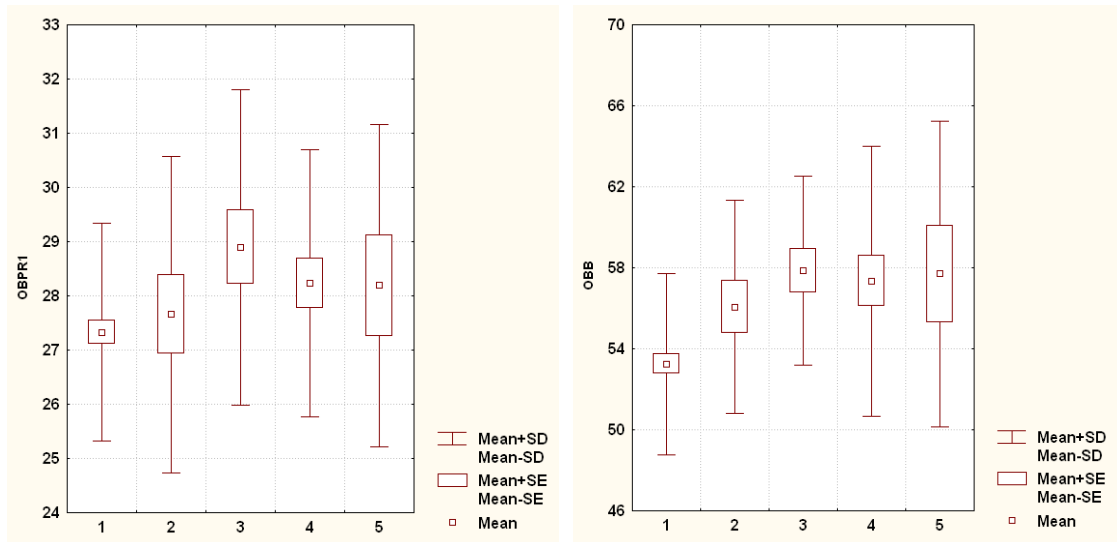

Fig. 3. Forearm girth in the upper part Fig. 4. Thigh girth (OBB) in healthy and sick (OBPR1) in healthy and sick men with various men with various forms of eczema $(\mathrm{cm})$ forms of eczema $(\mathrm{cm})$.
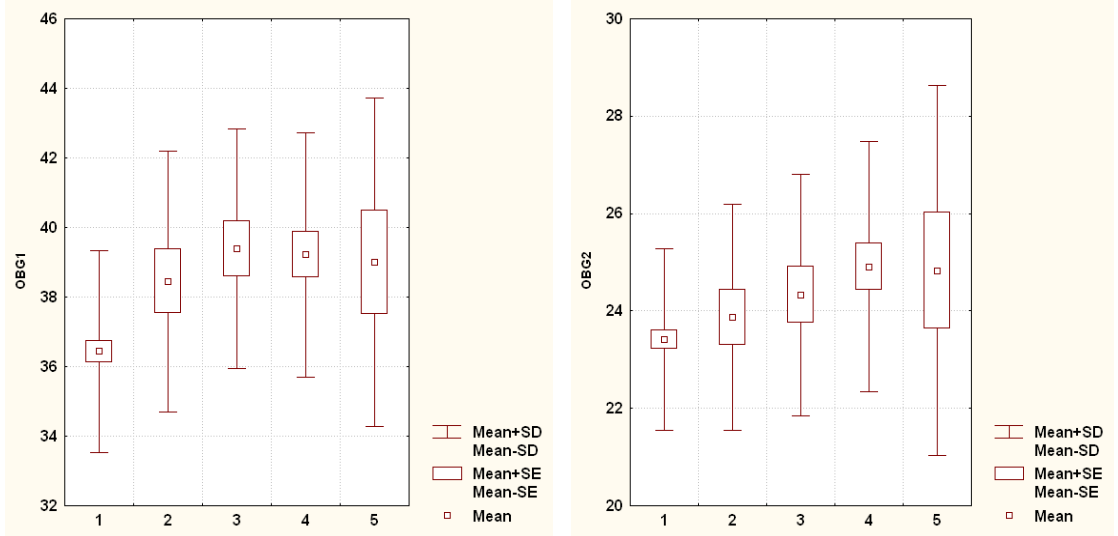

. Crus girth in the upper part (OBG1) in Fig. 7. Crus girth in the lower part (OBG2) in healthy and sick men with various forms of healthy and sick men with various forms of eczema $(\mathrm{cm})$.
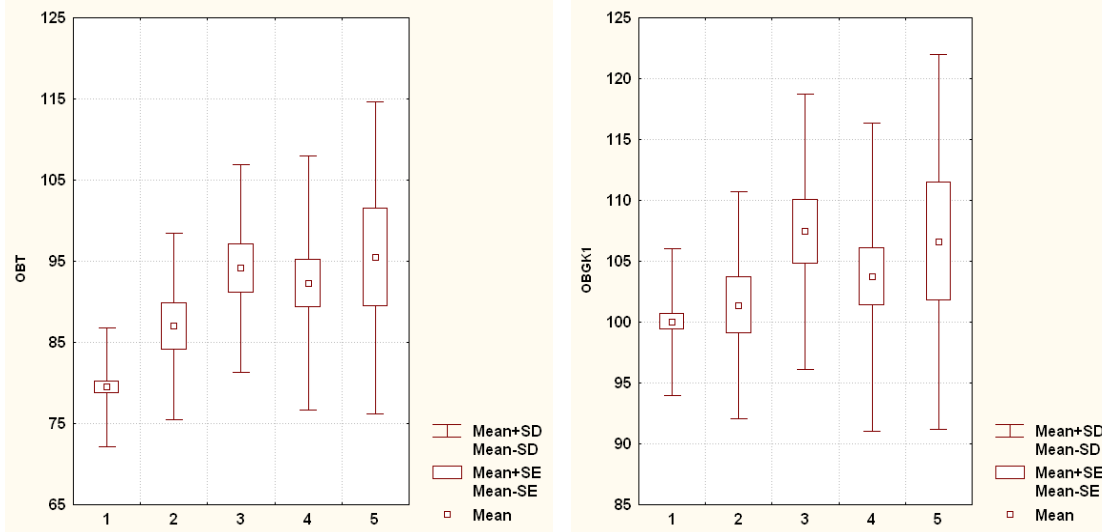

Fig. 9. Waist girth (OBT) in healthy and Fig. 10. Chest girth on inspiration (OBGK1) patients with various forms of eczema in men in healthy and sick men with various forms $(\mathrm{cm})$. $\quad$ of eczema $(\mathrm{cm})$. 


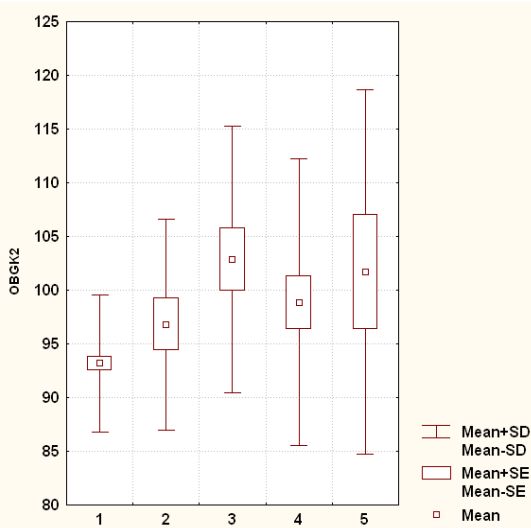

Fig. 11. Chest girth on exhalation (OBGK2) in healthy and patients with various forms of eczema in men $(\mathrm{cm})$.

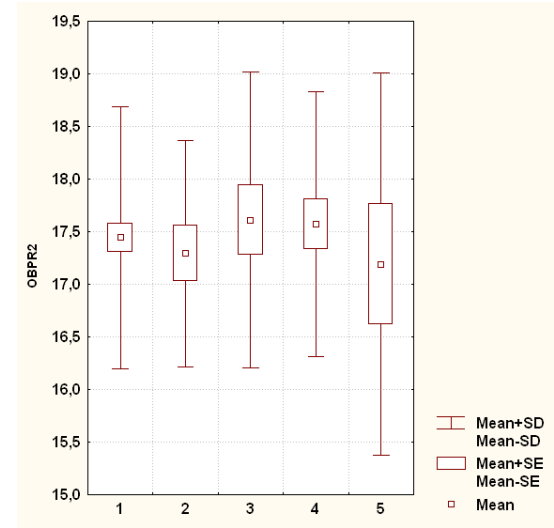

Fig. 14. Forearm girth in the lower part (OBPR2) in healthy and sick men with various forms of eczema $(\mathrm{cm})$.

(Fig. 8);

waist girth $(79.48 \pm 7.32)$ compared with men with idiopathic eczema of the mild $(86.97 \pm 11.54 ; p<0.05)$ and severe $(94.14 \pm 12.79 ; p<0.001)$ severity and microbial eczema of the mild $(92.30 \pm 15.67 ; p<0.001)$ and severe (95.45 $\pm 19.23 ; p<0.01$ ) severity (Fig. 9);

chest girth on inspiration (100.0 \pm 6.0$)$ compared with men suffering from idiopathic eczema of severe course (107.4 $\pm 11.3 ; p<0.05)$ (Fig. 10);

chest girth on exhalation (93.18 \pm 6.39$)$ compared with men with severe eczema of severe course (102.9 \pm 12.4 ; $\mathrm{p}<0.01$ ) (Fig. 11);

chest girth at rest $(95.20 \pm 6.57)$ compared with men with severe eczema $(104.7 \pm 12.0 ; p<0.01)$ (Fig. 12).

In healthy men, the girth of the foot $(24.96 \pm 1.46)$ is greater compared to sick men with mild microbial eczema (24.18 $\pm 2.08 ; p=0.076$ ) (Fig. 13).

The neck girth in sick men with idiopathic eczema of mild course $(38.25 \pm 2.37)$ is smaller compared with sick men with idiopathic eczema of severe course $(40.42 \pm 2.91$; p<0.05) (see Fig. 8).

Significant or tendencies of differences in the girth of

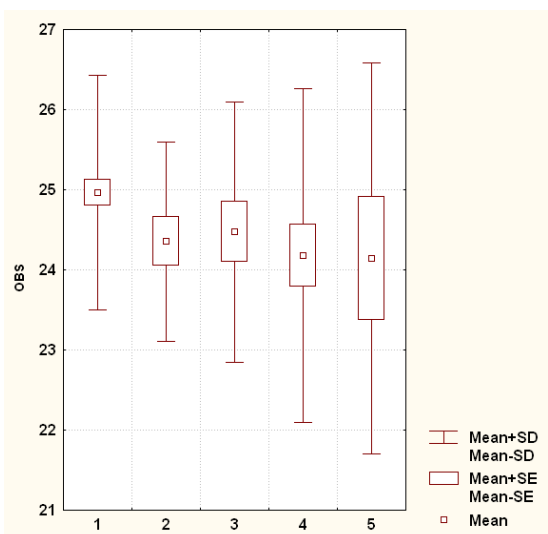

Fig. 13. Foot girth (OBS) in healthy and sick men with various forms of eczema $(\mathrm{cm})$.

the forearm in the lower part, the girth of the hand both between healthy and sick, and between men with various forms of eczema have not been established (Figs. 14, 15).

\section{Discussion}

Recently, more and more attempts are being made to take a constitutional approach to the search for morphological characteristics to differentiate patients with various diseases from the healthy population $[3,18,19]$.

In a number of studies, it was determined that in almost all studied sizes are more important in patients with acne, pyoderma, atopic dermatitis compared with healthy individuals of the same sex $[5,8,9,12,16]$. In addition, it is known that in patients with a picnic physique, the clinical symptoms of dermatoses are more intense than in persons with asthenic and normosthenic somatotypes [7]. Great mass in the structure of the body in some diseases is manifested not only in increasing weight and weight-growth indicators, but also in the relative shortening of the lower extremities and increasing the girth of the body [13].

In healthy men compared with patients with various forms of eczema found significantly lower or tendencies to lower values: shoulder girth in a tense state by $4.9 \%$ compared with patients with idiopathic eczema of severe course; shoulder girth in a relaxed state by $7.3 \%$ and 11.8 $\%$ compared with patients with idiopathic eczema of mild and severe course, by $10.0 \%$ and $11.3 \%$ compared with patients with microbial eczema of mild and severe course; forearm girth in the upper part by $5.4 \%$ compared with patients with idiopathic eczema of severe course; thigh girth by $5.1 \%$ and $8.0 \%$ compared with patients with idiopathic eczema of mild and severe course, by $7.1 \%$ and 
$11.3 \%$ compared with patients with microbial eczema of mild and severe course; thigh girth by $4.16 \%$ and $4.5 \%$ compared with patients with idiopathic severe eczema and microbial eczema of mild course; upper crus girth by $5.3 \%, 7.5 \%$ and $7.1 \%$ compared with patients with idiopathic eczema of mild and severe course and microbial eczema of mild course; lower crus girth by $6.0 \%$ compared with patients with mild microbial eczema; neck girth by 7.5 $\%$ and $6.8 \%$ compared with patients with idiopathic severe eczema and mild microbial eczema; waist girth by $8.6 \%$ and $15.6 \%$ compared with patients with idiopathic eczema of mild and severe course and by $13.9 \%$ and $16.7 \%$ compared with patients with microbial eczema of mild and severe course; chest girth on inhalation, exhalation, at rest by $6.9 \%, 9.5 \%$ and $9.1 \%$ compared with patients with idiopathic eczema of severe course.

Only the foot girth in healthy men was $3.1 \%$ higher than in patients with mild microbial eczema. In men with idiopathic eczema, the neck girth was $5.4 \%$ lower than in patients with severe eczema.

Thus, as a result of the work, for the first time, differences

\section{References}

[1] Barbarot, S., Auziere, S., Gadkari, A., Girolomoni, G., Puig, L., Simpson, E. L., ... \& Eckert, L. (2018). Epidemiology of atopic dermatitis in adults: results from an international survey. Allergy, 73(6), 1284-1293. doi: 10.1111/all.13401

[2] Bunak, V. V. (1941). Антропометрия [Anthropometry]. M.: Наркомпрос РСФСР - M.: People's Commissariat of the RSFSR.

[3] Chaplygina, E. V., Aksenova, O. A., Vartanova, O. T., Nor-Arevian, K. A., \& Evtushenko, A. V. (2014). Современные представления о конституции человека и ее значение для медицины [Modern ideas about the human constitution and its importance for medicine]. Современные проблемы науки и образования - Modern problems of science and education, (5), 468-468.

[4] Drucker, A. M., Wang, A. R., Li, W. Q., Sevetson, E., Block, J. K., \& Qureshi, A. A. (2017). The burden of atopic dermatitis: summary of a report for the National Eczema Association. Journal of Investigative Dermatology, 137(1), 26-30. doi: 10.1016/j.jid.2016.07.012

[5] Gara, A. V. (2014). Особливості соматотипологічних параметрів у хлопчиків і дівчаток Поділля хворих на атопічний дерматит [Features of somatotypological parameters in boys and girls of Podillya patients with atopic dermatitis]. $У_{K-}$ раїнський морфологічний альманах - Ukrainian morphological almanac, 12(2), 95-98.

[6] Klimov, N. lu., Vinnik, lu. lu., Andreichikov, A. V., \& Maksimov, A. S. (2018). Конституциональный подход в изучении болезней человека на современном этапе [Constitutional approach to the study of human diseases at the present stage]. Сеченовский вестник - Sechenovsky Bulletin, (4), 70-77. doi: 10.47093/22187332.2018.4.70-77 $(13,16)$

[7] Koleva, M., Nacheva, A., \& Boev, M. (2002). Somatotype and disease prevalence in adults. Reviews on environmental health, 17(1), 65-84. doi: 10.1515/REVEH.2002.17.1.65

[8] Krivko, lu. la., \& Chaplik-Chizho, I. O. (2016). Розбіжності обхватних розмірів тіла між здоровими і хворими на піодермії чоловіками та жінками [Differences in body size between healthy and pyoderma-sick men and women]. Ceim медицини та біології - World of medicine and biology, 1(55), in the girth size between healthy and patients with idiopathic and microbial eczema were revealed for Ukrainian men of the first mature age. Comprehensive dimensions can be used as a criterion of severity and to predict the phenotypic manifestation of eczema (risk group).

To determine subpathological ("diathetic") constitutional types in eczema, it is necessary to further study other anthropometric and somatotypological parameters of the body.

\section{Conclusions}

1. In men with different forms and severity of dermatosis, most of the girth of the body is larger (except for the girth of the foot) compared to healthy individuals.

2. There were no significant or trends in differences in body girth sizes between patients with idiopathic and microbial eczema, and almost no differences between patients with mild and severe disease (only the neck girth is significantly smaller in patients with idiopathic eczema of mild severity compared to severe).

53-55.

[9] Maievskyi, O. le., \& Makarchuk, I. М. (2014). Обхватні розміри тіла у здорових та хворих на вугрову хворобу юнаків та дівчат Поділля [Girth body size in healthy and acne-prone boys and girls of Podillya]. Світ медицини та біології World of medicine and biology, 4(46), 34-40.

[10] Markova, E. V., Fefelova, V. V., Nikolaev, V. G., \& Zakharova, L. B. (1997). Конституциональные особенности адаптивных возможностей человека [Constitutional features of human adaptive capabilities]. Актуальные вопросы биомедицинской и клинической антропологии - Topical issues of biomedical and clinical anthropology, 55-57.

[11] McElroy, A. (2018). Medical anthropology in ecological perspective. Routledge.

[12] Nahm, D. H. (2016). Associations of atopic dermatitis with obesity and unmarried status in young adults: evidence for atopic dermatitis as a life-style disorder with high social impact. Allergy, asthma \& immunology research, 8(2), 89-91. doi: 10.4168/aair.2016.8.2.89

[13] Nikitiuk, D. B. (2017) Уровень функциональных резервов организма человека и морфо-психо-функциональные соотношения [The level of functional reserves of the human body and morpho-psycho-functional relationships]. Poccuйский журнал реабилитационной медицины - Russian journal of rehabilitation medicine, (4), 3-14.

[14] Nikitiuk, B. A. (2010). Интеграция знаний в науках о человеке (Современная интегративная антропология) [Integration of knowledge in the human sciences (Modern integrative anthropology)]. М.: СпортАкадемПресс - М.: SportAcademPress.

[15] Nikitiuk, D. B., Nikolenko, V. N., Khairullin, R. M., Minnibaev, T. Sh., Chava, S. V., \& Alekseeva, N. T. (2013). Антропометрический метод и клиническая медицина [Anthropometric method and clinical medicine]. Журнал анатомии и гистопатологии - Journal of Anatomy and Histopathology, 2(2), 10-14.

[16] Nikolaev, V. G., Sindeeva, L. V., \& Maksimenko, V. G. (2006). Состав тела и псориаз: клинико-антропологические па- 
раллели [Body composition and psoriasis: clinical and anthropological parallels]. Ecтествознание и гуманизм:сб. науч. тр., Томск - Natural Science and Humanism: Collection of Scientific Papers, Tomsk, 3(3), 26-27.

[17] Nikolenko, V. N., Nikitiuk, D. B., \& Klochkova, C. V. (2017). Соматическая конституция и клиническая медицина [Somatic constitution and clinical medicine]. Общество с ограниченной ответственностью Издательский дом Практическая медицина - Limited Liability Company Publishing House Practical Medicine.

[18] Sakibaev, K. Sh. (2019). Обхватные размеры тела у муж- чин разных соматотипов [Body girth in men of different somatotypes]. Современные проблемы науки и образования - Modern problems of science and education, (1), 21-21. doi: $10.17513 /$ spno.28493

[19] Tutelian, V. A., Nikitiuk, D. B., Klochkova, S. V., Alekseeva, N. T., Pogonchenkova, I. V., Rassulova, M. A., ... \& Lavrinenko, S. V. (2018). Использование метода комплексной антропометрии в спортивной и клинической практике [Using the method of complex anthropometry in sports and clinical practice]. М.: Спорт - М.: Sport. 